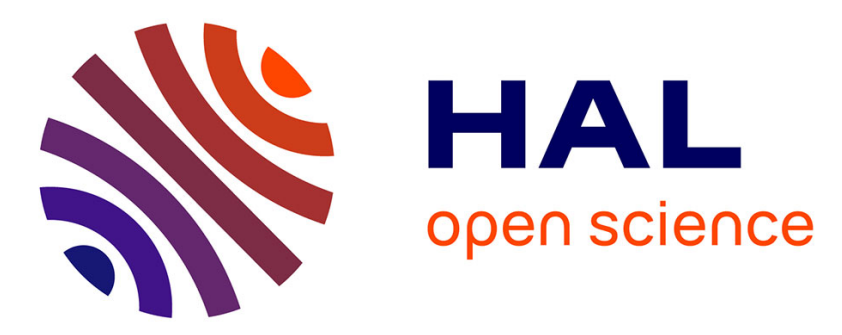

\title{
Impact of biomineralization on the preservation of microorganisms during fossilization: An experimental perspective
}

Jinhua Li, Sylvain Bernard, Karim Benzerara, Olivier Beyssac, Thierry Allard, Julie Cosmidis, Julien Moussou

\section{To cite this version:}

Jinhua Li, Sylvain Bernard, Karim Benzerara, Olivier Beyssac, Thierry Allard, et al.. Impact of biomineralization on the preservation of microorganisms during fossilization: An experimental perspective. Earth and Planetary Science Letters, 2014, 400, pp.113-122. 10.1016/j.epsl.2014.05.031 . hal-01050089

\section{HAL Id: hal-01050089 \\ https://hal.science/hal-01050089}

Submitted on 9 Jan 2015

HAL is a multi-disciplinary open access archive for the deposit and dissemination of scientific research documents, whether they are published or not. The documents may come from teaching and research institutions in France or abroad, or from public or private research centers.
L'archive ouverte pluridisciplinaire HAL, est destinée au dépôt et à la diffusion de documents scientifiques de niveau recherche, publiés ou non, émanant des établissements d'enseignement et de recherche français ou étrangers, des laboratoires publics ou privés. 

fossilization: an experimental perspective

3

4 Jinhua Li ${ }^{\text {a }}$, Sylvain Bernard ${ }^{\text {a, }}$, Karim Benzerara ${ }^{\text {a }}$, Olivier Beyssac ${ }^{\text {a }}$, Thierry Allard ${ }^{\text {a }}$, Julie Cosmidis ${ }^{\text {a }}$, 5 Julien Moussou ${ }^{\text {b }}$

6

$7{ }^{\text {a } I M P M C, ~ U M R ~ 7590, ~ C N R S, ~ M N H N, ~ U P M C, ~} 4$ place Jussieu, 75005 Paris, France

$8 \quad{ }^{\mathrm{b}}$ École Normale Supérieure, Paris, France

9

$10 *$ Corresponding author.

11 E-mail addresses: lijinhua@mail.iggcas.ac.cn (J.H. Li), sbernard@mnhn.fr (S. Bernard),

12 karim.benzerara@impmc.upmc.fr (K. Benzerara), olivier.beyssac@impmc.upmc.fr (O. Beyssac) 


\section{ABSTRACT}

The biogenicity of fossil microbial biomorphs is often debated because their morphologies are poorly informative and the chemical, structural and isotopic signatures of biogenic organic molecules have been

17 altered during their incorporation into the sediments and the geological history of the host rock. Here, we investigated the effect of encrustation by biominerals on the morphological and chemical degradation of Escherichia coli cells during experimental thermal treatments with the aim of simulating fossilization processes. Non-calcified E. coli cells and E. coli cells encrusted by calcium phosphates were exposed to

21 heating under an Argon atmosphere at two different temperatures $\left(300^{\circ} \mathrm{C}, 600^{\circ} \mathrm{C}\right)$ for different durations

$22(2 \mathrm{~h}, 20 \mathrm{~h}, 100 \mathrm{~h})$. Products were characterized down to the nm-scale using a combination of scanning 23 electron microscopy, transmission electron microscopy, Raman microspectroscopy, electron

24 paramagnetic resonance (EPR) spectroscopy, Fourier transform infrared (FT-IR) spectroscopy and 25 scanning transmission X-ray microscopy. In absence of encrusting biominerals, the morphological 26 structure of E. coli cells was completely lost after heating at 300 or $600^{\circ} \mathrm{C}$, even after short (2h) heating 27 experiments. E. coli cells heat-treated at $600^{\circ} \mathrm{C}$ for $20 \mathrm{~h}$ had an increased content of aromatic functional groups, and the amide functional groups were lost. Moreover, the EPR spectrum of these cells showed a supra-Lorentzian line shape, similar to the EPR spectrum of organic carbon detected in the Apex chert (ca. $3460 \mathrm{Myr}$ ) for example. In contrast, calcified E. coli exposed to the same conditions $\left(300\right.$ or $\left.600^{\circ} \mathrm{C}\right)$ showed limited morphological alteration as observed by electron microscopies and less chemical transformation as detected by FT-IR and EPR spectroscopies. These experiments evidence the strong influence of cell encrustation by minerals on their preservation potential during fossilization processes.

Keywords: Experimental taphonomy, Biomineralization, Fossilization, Exceptional preservation, EPR, 


\section{Introduction}

A wide diversity of microorganisms can form a variety of crystalline or amorphous biominerals via biomineralization within their cells, in their cell walls, at the cell surface, on extracellular structures and away from the cells (e.g., Lowenstam, 1981; Weiner and Dove, 2003; Konhauser and Riding, 2012). These biomineralization processes are relatively fast and can occur in a few hours or days (e.g., Miot et al., 2009; Chan et al., 2011), resulting in the formation of diverse organo-mineral complexes including biominerals and biomineral-encrusted cells/biostructures (Li J. H. et al., 2013). Recent analytical advances offer promises to characterize chemically and mineralogically these complexes down to the nmscale (e.g., Miot et al., in press). Encrustation of microbial cells by biominerals can be seen as a first stage of fossilization (e.g., Oehler and Schopf, 1971; Westall, 1995; Toporski et al., 2002; Benning et al., 2004; Lalonde et al., 2005; Miot et al., 2009; Orange et al., 2009; Li et al., 2010; Chan et al., 2011). It has often been hypothesized that biomineral-encrusted cells/biostructures may be more resistant to diagenesis and/or metamorphism than pure organic molecules and structures, and therefore that they may be better preserved over geological timescales (see Li J. H. et al., 2013 for a review). Yet, such assumptions have not yet been evidenced experimentally.

Assessing the biogenicity of microbial-like structures in ancient rocks is challenging since the original biological information they contain can be significantly altered during fossilization processes (e.g., Gourier et al., 2004; Vandenbroucke and Largeau, 2007; Papineau et al., 2010), and these biostructures may thus be mistaken with abiotic structures (Brasier et al., 2002; García-Ruiz et al., 2003; Van Zuilen et al., 2007; Cosmidis et al., 2013). In addition, determining unambiguously the syngenicity of putative microfossils within a rock requires a precise assessment of the thermal history that they have experienced (Brasier and Wacey, 2012).

Exposing modern microorganisms in the laboratory to well-constrained temperature conditions may help improving our knowledge on the transformations of such fossils induced by burial and maturation processes (Li J. H. et al., 2013). Such experiments have been used increasingly to study the thermal maturation of biomolecules or biominerals under various pressure and temperature conditions (e.g., Stankiewicz et al., 2000; Gupta et al., 2006; Skrzypczak-Bonduelle et al. 2008; Watson et al., 2012; Bourbin et al., 2013; Li Y. L. et al., 2013). For instance, Skrzypczak-Bonduelle et al. (2008) reported the continuous evolution of electron paramagnetic resonance (EPR) line shapes gradually from a GaussianLorentzian to a supra-Lorentzian profile for organic matter experiencing step-heating from room temperature up to $800^{\circ} \mathrm{C}$, similarly to what is reported for field samples. Similar results were recently obtained by Bourbin et al. (2013) on bacteria heat-treated in the laboratory, thereby confirming that EPR spectroscopy provides a powerful tool to study the geochemical maturity of organic matter. 
However, comparing extant microbes or biominerals with putative ancient microfossils or fossil biominerals is still a challenge as the impact of mineral encrustation on the preservation of microbial fossils has not yet been tested in detail ( $\mathrm{Li} \mathrm{J}$. H. et al., 2013). Here, we report results of thermal degradation experiments performed on Escherichia coli cells with or without Ca-phosphate encrusting their cell walls at 300 and $600^{\circ} \mathrm{C}$ under argon atmosphere for various durations (up to $100 \mathrm{~h}$ ). Thermally degraded cells were characterized using scanning electron microscopy (SEM), transmission electron microscopy (TEM), Raman microspectroscopy, EPR spectroscopy, Fourier-Transform infrared spectroscopy (FT-IR) and scanning transmission X-ray microscopy (STXM) coupled with X-ray absorption near edge structure (XANES) spectroscopy. These techniques are highly complementary. While Raman spectroscopy is sensitive to the organization of the aromatic skeleton in carbonaceous material (e.g., Beyssac et al., 2003; Lahfid et al., 2010; Beyssac and Lazari, 2012), EPR spectroscopy detects the electron spin of organic radicals in carbonaceous matter with high sensitivity (e.g., Mrozowski, 1988; Bourbin et al., 2013), C-XANES spectroscopy provides information on organic carbon speciation (e.g., Bluhm et al., 2006; Solomon et al., 2009), and FT-IR spectroscopy allows identifying the different chemical bonds within organic molecules (e.g., Yule et al., 2000).

\section{Materials and methods}

\subsection{Sample preparation}

Calcium-phosphate encrusted (i.e., calcified) and non-encrusted (i.e., non-calcified) E. coli cell samples used in the present study were derived from the same E. coli Apm1 strain. Strain Apm1 was obtained by transformation of E. coli BL 21 cells by the pET gene expression system (Studier and Moffatt, 1986). This plasmid contained (i) a phoa gene coding for an alkaline phosphatase linked to a promoter activated by isopropyl $\beta$-D-thiogalactoside (IPTG), and (ii) an ampicillin resistance marker. The addition of IPTG to the culture medium induced the transcription of the phoa gene, resulting in the overexpression of alkaline phosphatase enzymes (PHO A). Encrustation of the cells by Ca-phosphates was achieved by culturing cells over-expressing PHO A in a calcification medium.

To obtain cells encrusted by Ca-phosphates, cells from one single colony grown on LB agar medium (Sigma-Aldrich Co.), were inoculated within $5 \mathrm{ml}$ of autoclaved liquid LB medium (Sigma-Aldrich Co.) and grown overnight at $37^{\circ} \mathrm{C}$ and $180 \mathrm{rpm}$. This $5-\mathrm{ml}$ culture was transferred into $500 \mathrm{ml}$ of liquid LB for bacterial amplification culture. This culture was also carried out at $37^{\circ} \mathrm{C}$ and $180 \mathrm{rpm}$; the optical density at $600 \mathrm{~nm}\left(\mathrm{OD}_{600}\right)$ was monitored during the growth. Once the $\mathrm{OD}_{600}$ reached a value between 0.6 and 0.8 after $\sim 4-6 \mathrm{~h}$ incubation (corresponding to the exponential growth phase of $E$. coli cells), $1 \mathrm{ml}$ of IPTG $(0.4 \mathrm{mM})$ was added to induce the overexpression of the pho a gene, leading to the production by the cells of high amounts of PHO A. After 4-hours of incubation under these conditions, cells were harvested by 
centrifugation at $6500 \mathrm{rpm}$ for $15 \mathrm{~min}$ and rinsed three times with distilled water. Cells were then transferred to 2 liters of a calcification medium and incubated at $37^{\circ} \mathrm{C}$ with shaking at $120 \mathrm{rpm}$. The calcification medium, specifically designed to favor encrustation by Ca-phosphates, was prepared by dissolving calcium-glycerophosphate (glycerol phosphate calcium salt, Sigma-Aldrich Co.) in a HEPES (4-(2-hydroxyethyl)-1-piperazineethanesulfonic acid) pH-buffer $(20 \mathrm{mM})$. $\mathrm{HCl}(1 \mathrm{M})$ was used to adjust the $\mathrm{pH}$ to 7.5 and the medium was sterilized by filtration through a $0.22-\mu \mathrm{m}$ filter. After a week, the incubated cells, completely encrusted by Ca-phosphates were centrifuged at $8000 \mathrm{rpm}$ for $15 \mathrm{~min}$ and rinsed three times in distilled water.

To obtain the non-encrusted E. coli cells, 2-ml suspension of precultured Apm1 were transferred into 1 liter of liquid LB medium and allowed to grow overnight, and then harvested by centrifugation and rinsed with distilled water using the same protocol as for the calcified E. coli.

All media contained a final concentration of ampicillin of $50 \mu \mathrm{g} \cdot \mathrm{ml}^{-1}$ to prevent growth of potential contaminants.

\subsection{Thermal treatments}

Calcified and non-calcified E. coli cells were first dehydrated at ambient temperature in a vacuum dryer for two weeks at ambient temperature (i.e. $\sim 20^{\circ} \mathrm{C}$ ), and then heat-treated at different temperatures (i.e., 300 and $600^{\circ} \mathrm{C}$ ) for various durations (i.e., 2, 20 and $100 \mathrm{~h}$ ) in an inert Argon atmosphere using a Carbolite single zone horizontal tube furnace (GHA12/300) equipped with a Quartz work-tube. For all experiments, the increase of temperature followed a constant ramp of $5^{\circ} \mathrm{C} \cdot \mathrm{min}^{-1}$. Experimental solid products were characterized using SEM and TEM while their chemical, structural and molecular signatures were analysed by Raman, EPR, XANES and FT-IR spectroscopies.

\subsection{SEM and TEM}

Experimental solid products were finely ground in distilled water. Samples for SEM were deposited on cover slides $(\sim 3 \mathrm{~mm} \times 3 \mathrm{~mm})$ mounted on aluminum SEM stubs with high-conductivity copper tape. Samples for SEM were coated with carbon or gold. SEM observations were performed on a Zeiss Supra 55 SEM microscope at a $10 \mathrm{kV}$ accelerating voltage and a working distance of $7.5 \mathrm{~mm}$. SEM images were collected with both in-Lens and Angle selective Backscattered (AsB) detectors. Samples for TEM analyses were deposited on carbon coated Formvar grids. TEM experiments were carried out on a JEOL$2100 \mathrm{~F}$ microscope operating at $200 \mathrm{kV}$, equipped with a field emission gun, an ultra high-resolution (UHR) pole piece, a Gatan energy filter GIF 200, a JEOL detector with an ultrathin window allowing detection of light elements, and a scanning TEM (STEM) device, which allows Z-contrast imaging in 
high angle annular dark field (HAADF) mode. Elemental mapping was acquired by EDXS (energy dispersive X-ray spectroscopy) in the STEM mode.

\subsection{Raman spectroscopy}

Raman data were obtained on powders with a Renishaw INVIA microspectrometer as described in Bernard et al. (2008). Spectra were measured from 500 to $3500 \mathrm{~cm}^{-1}$ at constant room temperature using the $514.5 \mathrm{~nm}$ wavelength of a $50 \mathrm{~mW}$ Modulaser Argon laser (green laser) focused on the sample through a Leica DMLM microscope with a long working distance 50X objective $(\mathrm{NA}=0.55)$. This configuration yielded a planar resolution of $\sim 1 \mu \mathrm{m}$ for a laser power delivered at the sample surface set at around 250 $\mu \mathrm{W}$ to prevent irreversible thermal damage that could be due to laser-induced heating (Beyssac et al., 2003). Light was dispersed by a grating with 1800 lines/mm and the signal was analyzed with a RENCAM CCD detector. Measurements were performed with a circularly polarized laser using a $1 / 4$ wavelength plate placed before the microscope in order to limit polarization effects. The collected Raman signal was fitted using the procedure introduced by Lahfid et al. (2010). Additional Raman analyses were performed using the $785 \mathrm{~nm}$ wavelength of a $300 \mathrm{~mW}$ Renishaw diode laser (near-infrared laser) with a planar resolution of $\sim 2-3 \mu \mathrm{m}$ and low laser power. As this configuration did not improve the signal-tofluorescence ratio, only data collected using the green laser are presented here.

\subsection{EPR spectroscopy}

EPR data were collected on powders at room temperature at the X-band $(9.86 \mathrm{GHz})$ using a BRUKER EMX spectrometer with the following parameters: center field $3530 \mathrm{G}$, modulation frequency $100 \mathrm{kHz}$, microwave power $1 \mathrm{~mW}$, and modulation amplitude $0.3 \mathrm{G}$. The spectrometer was calibrated using the diphenylpicrylhydrazyl (DPPH) standard with a known $g$ factor ( $g$ = 2.0037). As the detection scheme of EPR gave spectra in the forms of a first derivative of the EPR absorption, a plot of $\left[A_{\mathrm{pp}} \Delta B /\left(\Delta B_{\mathrm{pp}} A\right)\right]^{1 / 2}$ versus $\left(\Delta B / \Delta B_{\mathrm{pp}}\right)^{2}$ was used to further characterize the line shape by its deviation from a pure Lorentzian line, where $\Delta B_{\mathrm{pp}}$ and $A_{\mathrm{pp}}$ are the peak-to-peak line width and amplitude, respectively, $\Delta B$ is the magnetic field offset from this line center, and $A$ is EPR amplitude values at each point of the EPR line (Skrzypczak-Bonduelle, 2008). The line shape parameter $R_{10}$, which quantified the deviations of the experimental points from the Lorentzian shape in this plot, was calculated following SkrzypczakBonduelle et al. (2008).

\subsection{STXM-based XANES spectroscopy}

Experimental solid products were finely ground and deposited on $\mathrm{Si}_{3} \mathrm{~N}_{4}$ windows for STXM analyses. XANES data were collected on beamline 5.3.2.2 (STXM Polymer beamline - Kilcoyne et al., 
171

172

173

174

175

176

177

178

179

180

181

182

183

184

185

186

187

188

189

190

191

192

193

194

195

196

197

198

199

200

201

202

203

204

2003) at the Advanced Light Source (ALS) and beamline 10ID-1 (SM beamline - Kaznatcheev et al., 2007) at the Canadian Light Source (CLS). Beamline 5.3.2.2 (ALS) works in the soft X-ray energy range $(250-800 \mathrm{eV})$ and is based on a bending magnet. The ALS storage ring was operated at $1.9 \mathrm{GeV}$ and 500 mA current in a top-up mode. Beamline 10ID-1 (CLS) works in the soft X-ray energy range (130 - 2500 $\mathrm{eV}$ ) and is based on an elliptically polarized undulator (EPU). The CLS storage ring was operated at 2.9 $\mathrm{GeV}$ and between 100 and $250 \mathrm{~mA}$ current. On both beamlines, the microscope chamber was first pumped down to 100 mTorr after sample insertion and back-filled with He.

Rationale for the use of STXM to study biominerals can be found in Cosmidis and Benzerara (2014). Energy calibration was accomplished using the well-resolved 3p Rydberg peak at $294.96 \mathrm{eV}$ of gaseous $\mathrm{CO}_{2}$ for the $\mathrm{C} \mathrm{K}$-edge. Alignment of images of stacks and extraction of XANES spectra were done using the aXis2000 software (ver2.1n). Normalization and assessment of spectral peak positions were determined using the Athena software package (Ravel and Newville, 2005). Extensive databases of reference C-XANES spectra were available from the literature (e.g., Solomon et al., 2009).

\subsection{FT-IR Spectroscopy}

Experimental solid products were finely ground, diluted within dried potassium bromide $(\mathrm{KBr})$, and pressed under 8 tons of pressure for 1 min to be characterized by FT-IR spectroscopy. FT-IR spectra were recorded between 400 and $4000 \mathrm{~cm}^{-1}$ with a resolution of $0.5 \mathrm{~cm}^{-1}$ by using a Nicolet 7600 FT-IR spectrometer. Two hundred absorbance spectra were obtained and averaged for each sample.

\section{Results}

\subsection{Electron microscopy}

After dehydration, non-calcified Apm1 cells display a rod-shaped morphology typical of $E$. coli cells, with a width of $\sim 0.5-0.8 \mu \mathrm{m}$ and a length of $\sim 1-3 \mu \mathrm{m}$ (Fig. 1a). In contrast, calcified Apm1 cells appear as large aggregates of cells encrusted heavily by calcium phosphates that can be observed at the cell surface as well as within the cells and the cell walls (Fig. 1c and Fig. S1a-c). STEM-EDXS mapping, HRTEM imaging, and selected area electron diffraction (SAED) analyses reveal that these calcium phosphates are poorly crystalline with d-spacing values (e.g., $3.46 \AA$ and $2.73 \AA$ ) consistent with those of hydroxyapatite (HA) (Cuisinier et al., 1987) (Fig. S1d-k).

Cell structures of non-calcified E. coli were completely disrupted after all heat-treatments, including at $300^{\circ} \mathrm{C}$ for $2 \mathrm{~h}$ (Fig. 1b). In contrast, calcified E. coli cells appeared well preserved morphologically after all thermal degradation experiments, including heat-treatment at $600^{\circ} \mathrm{C}$ for $20 \mathrm{~h}$ (Fig. 1d). The morphological and chemical features of calcified E. coli cells and their associated minerals remained relatively constant upon heating as evidenced by SEM, TEM and STEM-EDXS analyses except for the 
crystallinity of calcium phosphates, which increased with temperature as shown qualitatively by SAED and HRTEM analyses (Fig. S2).

\subsection{Raman and EPR spectroscopy}

Raman microspectroscopy is sensitive to the organization of the aromatic skeleton in graphitic carbons at the micrometer-scale (Bernard et al., 2010), while EPR spectroscopy is a bulk technique sensitive to the physiochemical structures of aromatic radical moieties (Mrozowski, 1988). These two techniques were used to characterize the solid products obtained after various thermal degradation experiments. However, the very high fluorescence overwhelming the Raman signal prevented collecting Raman data on most of the experimental solid products except for non-calcified E. coli cells heated at $600^{\circ} \mathrm{C}$ for $20 \mathrm{~h}$ (Fig. 2a). The Raman spectrum of this sample exhibited two dominant broad features centered at about 1360 and $1605 \mathrm{~cm}^{-1}$. These two features could be assigned to the main defect D1 band centered at $1355 \mathrm{~cm}^{-1}$, and to a composite band including the graphite $\mathrm{G}$ and the D2 defect bands. Additionally, an intense D3 defect band centered at $\sim 1515 \mathrm{~cm}^{-1}$ was clearly present. Such a spectrum was highly similar to the Raman spectra of partially combusted organic compounds such as soots, charcoals or organic residues of wood fires (e.g., Paris et al., 2005; Sadezky et al., 2005).

X-band EPR spectra were collected on both calcified and non-calcified E. coli cells heat-treated at $600^{\circ} \mathrm{C}$ for $20 \mathrm{~h}$ (Fig. 2b). Although both samples were characterized by the same EPR center ( 3535 G),

they exhibited different EPR spectra in terms of line shape and width. The line width parameter $\Delta B_{\mathrm{pp}}$ was $0.246 \mathrm{mT}$ for non-calcified E. coli cells heated at $600^{\circ} \mathrm{C}$ for $20 \mathrm{~h}$ and $0.441 \mathrm{mT}$ for calcified E. coli cells heated at $600^{\circ} \mathrm{C}$ for $20 \mathrm{~h}$. The EPR line shape of heated calcified E. coli cells was a combination of Gaussian and Lorentzian profiles with a $R_{10}$ factor of 0.82 , while the heated non-calcified $E$. coli cells exhibited a supra-Lorentzian EPR line shape (close to 2-D dipolar) with a $R_{10}$ factor of -1.85 (Fig. 2c), typical of more mature natural organic matter (Skrzypczak-Bonduelle et al., 2008; Bourbin et al., 2013).

\subsection{STXM-based XANES spectroscopy}

STXM-based XANES spectroscopy was used to document the evolution of carbon speciation in noncalcified E. coli cells heated at increasing temperatures for various durations (Fig. 3). STXM measurements could not be performed on calcified E. coli cells since they were opaque to X-rays because of heavy encrustation.

The C-XANES spectrum of non-heated and non-calcified $E$. coli cells was similar to the spectra measured for other bacteria by previous studies (e.g., Benzerara et al., 2004; Miot et al., 2009; Li J. H. et al., 2013), with a main peak at $288.2 \mathrm{eV}$, attributed to $1 s \rightarrow \pi^{*}$ electronic transitions of carbon in amide groups, a peak at $285.2 \mathrm{eV}$, attributed to electronic transitions of carbon in aromatic or olefinic carbon 
groups $(\mathrm{C}=\mathrm{C})$ and two additional peaks at $287.3 \mathrm{eV}$ and $289.4 \mathrm{eV}$, attributed to $1 \mathrm{~s} \rightarrow \pi^{*}$ electronic transitions of carbon in hydroxyl $(\mathrm{C}-\mathrm{OH})$ functional groups associated with phenols, and aryl ethers or hydroxylated aromatics and $\mathrm{C} 1 \mathrm{~s} \rightarrow 3 \mathrm{p} / \sigma^{*}$ electronic transitions of carbon in hydroxylated- or ether-linked carbon species, respectively (Solomon et al., 2009).

The intensity and the width of the peak at $285.2 \mathrm{eV}$ progressively increased with increasing heating duration at $300^{\circ} \mathrm{C}$, while the intensity of the peak at $288.2 \mathrm{eV}$ decreased and its width increased. The broadening of the peak at $288.2 \mathrm{eV}$ might be related to the increase of aliphatic and carboxylic group contents, which have major absorption peaks at $287.8 \mathrm{eV}$ and $288.5 \mathrm{eV}$, respectively.

With increasing temperature, the spectral evolution of heat-treated non-calcified E. coli cells was even more pronounced. At $600^{\circ} \mathrm{C}$, the peak at $288.2 \mathrm{eV}$ almost disappeared, suggesting massive loss of amide functional groups. Based on C-XANES spectra, non-calcified E. coli cells heat-treated at $600^{\circ} \mathrm{C}$ were composed of aliphatic-rich organic molecules dominated by poorly condensed aromatic structures (Solomon et al., 2009).

\subsection{FT-IR spectroscopy}

Non-calcified and non-heated E. coli cells showed a FT-IR spectrum very similar to spectra of bacteria reported in the literature (e.g., Filip et al., 2008). Three major peaks could be observed at 1655 $\mathrm{cm}^{-1}, 1540 \mathrm{~cm}^{-1}$, and $1237 \mathrm{~cm}^{-1}$ and were attributed based on previous studies to amide I, amide II, and amide III vibrational modes, respectively (Fig. 4a). Noticeably, $\mathrm{C}-\mathrm{O}$ and $\mathrm{C}=\mathrm{C}$ stretchings may also contribute to these peaks. The band at $1455 \mathrm{~cm}^{-1}$ was assigned to $\mathrm{C}-\mathrm{H}$ deformations of $\mathrm{CH}_{2}$ or $\mathrm{CH}_{3}$ groups in aliphatics; the band at $1393 \mathrm{~cm}^{-1}$ to $\mathrm{C}-\mathrm{H}$ bending $\left(-\mathrm{CH}_{3}\right.$ stretch in fatty acids); the band at $1082 \mathrm{~cm}^{-1}$ to $\mathrm{C}=\mathrm{O}$ asymmetric stretching (glycopeptides, ribose, aliphatic esters), and the band at $2958-2854 \mathrm{~cm}^{-1}$ to C$\mathrm{H}$ stretching in aliphatics of cell walls (fatty acids, carbohydrates) (e.g., Filip et al., 2004 and references therein). Consistently with C-XANES data, the FT-IR spectra of heat-treated non-calcified E. coli cells varied with increasing temperature indicating some chemical transformation of the organic carbon composing the cells: the peaks of amide $\left(1655 \mathrm{~cm}^{-1}, 1540 \mathrm{~cm}^{-1}\right.$, and $\left.1237 \mathrm{~cm}^{-1}\right)$, aliphatics $(2958-2854$ $\mathrm{cm}^{-1}, 1455 \mathrm{~cm}^{-1}$, and $\left.1393 \mathrm{~cm}^{-1}\right)$ and carbonyl or carboxyl groups $\left(1082 \mathrm{~cm}^{-1}\right)$ progressively disappeared when samples were heated up to $600^{\circ} \mathrm{C}$. Peaks at $1628 \mathrm{~cm}^{-1}, 1702 \mathrm{~cm}^{-1}$ and $1265 \mathrm{~cm}^{-1}$, assigned to aromatic $\mathrm{C}=\mathrm{C}, \mathrm{C}-\mathrm{O}$ bonds of $\mathrm{CO}_{2} \mathrm{H}$ groups and $\mathrm{C}=\mathrm{O}$ bonds of $\mathrm{COOH}$ groups, respectively (e.g., Tseng et al., 1996; Smidt et al., 2005), could be observed in non-calcified E. coli cells heat-treated at $300^{\circ} \mathrm{C}$ for 20 h. Infrared absorption of non-calcified E. coli cells heated at higher temperature $\left(600^{\circ} \mathrm{C}\right.$ for $\left.20 \mathrm{~h}\right)$ could not be measured, since this sample highly reflected the IR beam (Fig. 4a). Such high reflectivity likely traduced an important maturity level (e.g., Lis et al., 2005). 
Amide $\left(1652 \mathrm{~cm}^{-1}, 1540 \mathrm{~cm}^{-1}, 1237 \mathrm{~cm}^{-1}\right)$ and aliphatics $\left(1455 \mathrm{~cm}^{-1}, 2958-2854 \mathrm{~cm}^{-1}\right)$ bands could

273 be observed in the FT-IR spectrum of initial calcified E. coli cells, although this spectrum was dominated 274 by the characteristic $\mathrm{PO}_{4}{ }^{3-}$ absorption bands at 565, 603 and $1035 \mathrm{~cm}^{-1}$ (bending and stretching modes of 275 P-O groups and stretching and vibrational modes of $\mathrm{OH}^{-}$groups) (Fig. 4b), indicative of the Ca-phosphate 276 minerals encrusting the cells (e.g., Pleshko et al., 1991; Bazin et al., 2012). Additional weak features at $2771455 \mathrm{~cm}^{-1}$ and $1415 \mathrm{~cm}^{-1}$ were attributed to aliphatic and aromatic carbons, respectively (e.g., Trchová 278 and Stejskal, 2011). Interestingly, the FT-IR spectra of calcified E. coli cells did not change significantly 279 during thermal treatment at 300 or $600^{\circ} \mathrm{C}$ in contrast to non-calcified E. coli cells. The FT-IR spectrum of 280 calcified $E$. coli cells heat-treated at $600^{\circ} \mathrm{C}$ for $20 \mathrm{~h}$ appeared quite similar to the FT-IR spectrum of initial calcified E. coli cells, despite a slight decrease of the relative intensities of amide bands and a slight increase of the relative intensities of aliphatic $\left(1455 \mathrm{~cm}^{-1}\right)$ and aromatic $\left(1415 \mathrm{~cm}^{-1}\right)$ bands (Fig. $\left.4 \mathrm{~b}\right)$. Noteworthy, the peaks corresponding to amide functional groups were still detected even after thermal treatment at $600^{\circ} \mathrm{C}$ for $20 \mathrm{~h}$ and their presence interpreted as resulting from the (partial) preservation of the original molecular signatures of original biomolecules.

\section{Discussion}

\subsection{Impact of biomineralization on the preservation of bacteria}

Calcified E. coli cells were morphologically and chemically better preserved upon heating than noncalcified E. coli cells. This result was clearly evidenced by electron microscopy, EPR and FT-IR data. Calcified cells heat-treated at $600^{\circ} \mathrm{C}$ for $20 \mathrm{~h}$ exhibited a wider EPR spectrum than non-calcified cells, with $\Delta B_{\mathrm{pp}}$ of $0.441 \mathrm{mT}$ and $R_{10}$ factor of 0.82 (Figs. 1 and 2) which is typical of low maturity organic matter (Skrzypczak-Bonduelle et al., 2008). Consistently, FT-IR spectroscopy evidenced the slight chemical transformations of calcified $E$. coli cells with increasing temperature compared to the strong transformations undergone by non-calcified E. coli cells (Fig. 4).

The pervasive Ca-phosphate precipitation within the cell structures can explain the better morphological preservation of the cells during heating as it may have provided a mechanical resistance. In addition to a morphological preservation, the present study also evidenced the chemical preservation of calcified E. coli cells upon heating. A similar chemical resistance to thermal treatments was recently evidenced in experiments performed on bio-encrusted cells of iron-oxidizing bacteria, which formed amorphous iron phosphate minerals within the cell walls (Li J. H. et al., 2013). Periplasmic encrustation

302 by Ca-phosphates as observed here has been suggested to be a widespread mechanism (e.g., Goulhen et 303 al., 2006; Benzerara et al., 2008; Miot et al., 2009, 2011; Cosmidis et al., 2013; Li J. H. et al., 2013) and 304 may cause sorption and entrapment of organic molecules such as peptidoglycan proteins and 305 polysaccharides on/within minerals (e.g., Miot et al., 2009, 2011). Such organic-mineral complexes may 
facilitate the preservation of bacterial cell ultrastructural details, and potentially their chemical signatures, by shielding and protecting organic molecules from reactive solutions and/or oxidizing gas phases.

This mechanism remains hypothetical and deserves further experimental work. However, the present observations can be related to numerous previous reports that showed that even poorly resistant organic molecules such as amino acids or polysaccharides can be preserved during diagenesis if encapsulated within mineral biostructures such as coral skeletons and diatoms (e.g., Ingalls et al., 2003a, 2003b) or microbialites (e.g., Benzerara et al., 2006; Kaur et al., 2011). A major role for minerals in organic matter protection has also been recognized for soils and the occurrence of adsorptive protection of organic compounds as molecular monolayers onto clay minerals has been shown to be efficient against diagenetic degradation (e.g., Hedges and Keil, 1995; Ransom et al., 1998; Vandenbroucke and Largeau, 2007).

\subsection{Comparison with field sample spectroscopic signatures}

Extrapolating laboratory results to natural processes remains difficult, notably because geological durations cannot be replicated in the laboratory. Temperatures and heating rates considerably higher than those encountered in nature have traditionally been applied to laboratory samples to compensate for long geological time periods (e.g., Vandenbroucke and Largeau, 2007).

Here, non-calcified E. coli cells experimentally heat-treated at $600^{\circ} \mathrm{C}$ for $20 \mathrm{~h}$ exhibited a Raman spectrum which appeared markedly different from spectra of organic carbons having experienced diagenetic burial in natural settings, but pretty similar to spectra from soots or charcoals, i.e. organic residues having experienced only a short (on geological timescale) thermal treatment in nature. Furthermore, the high reflectivity of this sample as highlighted by FT-IR spectroscopy indicated a relatively high maturity (e.g., Lis et al., 2005). In addition, this sample exhibited a supra-Lorentzian EPR line shape (close to 2-D dipolar) with a $R_{10}$ factor of -1.85 , similar to the EPR lineshape shown by natural organic matter detected in the Apex cherts (ca. 3460 Myr) from Pilbara craton in Australia (e.g., the $R_{10}$ factor is -1.98), which is thought to have experienced metamorphic conditions in the Prehnite-Pumpellyite facies to lower Greenschist facies, i.e. temperature conditions of about $200-300^{\circ} \mathrm{C}$ (Skrzypczak-Bonduelle et al., 2008). Last, the absence in the C-XANES spectrum of $E$. coli cells heat-treated at $600^{\circ} \mathrm{C}$ for $20 \mathrm{~h}$ of a sharp $1 \mathrm{~s} \rightarrow \sigma^{*}$ exciton at $291.7 \mathrm{eV}$, related to the presence of extensive planar domains of highly conjugated aromatic layers (Ahuja et al., 1996; Bernard et al., 2010), suggested that the aromatic cluster size of these residues did not significantly increase even after having experienced such temperature conditions. Overall, this C-XANES spectrum appeared similar to C-XANES spectra of overmature kerogens (Bernard et al., 2012), i.e., kerogens having experienced a thermal history with a maximum temperature of about $200-250^{\circ} \mathrm{C}$. 
Altogether, Raman, FT-IR, EPR and C-XANES data obtained on non-calcified E. coli cells heattreated at $600^{\circ} \mathrm{C}$ for 20 hours provide contrasted views when compared to natural carbons: they looked like natural samples that have experienced short thermal pulse for Raman; less than $200-250^{\circ} \mathrm{C}$ for EPR and XANES. Difficulties to relate directly the products from laboratory experiments with field samples partly come from the heating rate and pressure conditions at which the present experiments were conducted. Heating rate and pressure have indeed been shown to be key factors impacting the kerogen decomposition rate (Beyssac et al., 2003; Vandenbroucke and Largeau, 2007). In addition, organic maturation processes in natural low-temperature systems may also be strongly affected by the presence of water (Seewald et al., 2000; Lewan and Roy, 2011), which was rapidly lost in the present experiments. Therefore, it will be important in the future to document further whether the differential evolution between calcified and non-calcified $E$. coli cells detected here may also take place when these additional parameters (e.g., heating rates, pressure and water) are involved.

351

\section{Concluding remarks}

In the present study, we investigated experimentally the impact of early encrustation by biominerals on the morphological and chemical transformations of E. coli cells upon heating. While in the absence of biominerals, E. coli cells were almost totally degraded, calcified E. coli were better preserved, morphologically and chemically, during thermal treatment at 300 or $600^{\circ} \mathrm{C}$, for durations as long as $100 \mathrm{~h}$. Such results clearly evidence the influence of bio-encrustation on bacteria preservation potential during fossilization processes. The resistance of such organic-mineral complexes to diagenesis clearly illustrates why self-encrusting microorganisms should be considered as pertinent targets for the search for evidence of ancient life in the fossil record.

\section{Acknowledgements}

We gratefully acknowledge supports from the Simone and Cino Del Duca Fundation and the ERC projects [Calcyan (Leaded by K. Benzerara) and PaleoNanoLife (Leaded by F. Robert)]. The SEM and TEM experiments have been performed at the IMPMC (CNRS-UPMC, Paris). The JEOL JEM2100F at the IMPMC was supported by Region Ile de France grant SESAME 2000 E 1435, INSU CNRS, INP CNRS and University Pierre et Marie Curie Paris 6. The focused ion beam (FIB) and SEM facilities of the IMPMC were supported by Region Ile de France grant SESAME 2006 I-07-593/R, INSU-CNRS, INP-CNRS, University Pierre et Marie Curie Paris 6. STXM data were acquired at beamline 5.3.2.2 at the

372 CIHR, the NRC, and the University of Saskatchewan. Special thanks go to David Kilcoyne for his expert 
373 support of the STXM at the ALS and to Chithra Karunakaran and Jian Wang for their expert support of 374 the STXM at the CLS.

375 


\section{References}

Ahuja, R., Bruhwiler, P.A., Wills, J.M., Johansson, B., Martensson, N., Eriksson, O., 1996. Theoretical and experimental study of the graphite 1s x-ray absorption edges. Phys. Rev. B 54, 14396-14404.

Bazin, D., Daudon, M., Combes, C., Rey, C., 2012. Characterization and some physicochemical aspects of pathological microcalcifications. Chem. Rev. 112, 5092-5120.

Benning, L.G., Phoenix, V.R., Yee, N., Konhauser, K.O., 2004. The dynamics of cyanobacterial silicification: An infrared micro-spectroscopic investigation. Geochim. Cosmochim. Acta 68, 743-757.

Benzerara, K., Menguy, N., Lopez-Garcia, P., Yoon, T.H., Kazmierczak, J., Tyliszczak, T., Guyot, F., Brown, G.E., 2006. Nanoscale detection of organic signatures in carbonate microbialites. Proc. Natl. Acad. Sci. U. S. A. 103, 9440-9445.

Benzerara, K., Morin, G., Yoon, T.H., Miot, J., Tyliszczak, T., Casiot, C., Bruneel, O., Farges, F., Brown, G.E., 2008. Nanoscale study of As biomineralization in an acid mine drainage system. Geochim. Cosmochim. Acta 72, 3949-3963.

Benzerara, K., Yoon, T.H., Tyliszczak, T., Constantz, B., Spormann, A.M., Brown, G.E., 2004. Scanning transmission X-ray microscopy study of microbial calcification. Geobiology 2, 249-259.

Bernard, S., Beyssac, O., Benzerara, K., 2008. Raman mapping using advanced line-scanning systems: Geological applications. Appl. Spectrosc. 62, 1180-1188.

Bernard, S., Beyssac, O., Benzerara, K., Findling, N., Tzvetkov, G., Brown, G.E., Jr., 2010. XANES, Raman and XRD study of anthracene-based cokes and saccharose-based chars submitted to hightemperature pyrolysis. Carbon 48, 2506-2516.

Bernard, S., Horsfield, B., Schulz, H.M., Wirth, R., Schreiber, A., Sherwood, N., 2012. Geochemical evolution of organic-rich shales with increasing maturity: A STXM and TEM study of the Posidonia Shale (Lower Toarcian, northern Germany). Mar. Pet. Geol. 31, 70-89.

Beyssac, O., Brunet, F., Petitet, J.-P., Goffe, B., Rouzaud, J.-N., 2003. Experimental study of the microtextural and structural transformations of carbonaceous materials under pressure and temperature. Eur. J. Mineral. 15, 937-952

Beyssac, O., Lazzeri, M., 2012. Application of Raman spectroscopy to the study of graphitic carbons in the Earth Sciences. In: Applications of Raman Spectroscopy to Earth Sciences and Cultural Heritage (J. Dubessy, M.-C. Caumon and F. Rull, editors). EMU Notes in Mineralogy, 12, 415454. European Mineralogical Union and the Mineralogical Society of Great Britain \& Ireland.

Bluhm, H., Andersson, K., Araki, T., Benzerara, K., Brown, G.E., Dynes, J.J., Ghosal, S., Gilles, M.K., Hansen, H.C., Hemminger, J.C., Hitchcock, A.P., Ketteler, G., Kilcoyne, A.L.D., Kneedler, E., Lawrence, J.R., Leppard, G.G., Majzlan, J., Mun, B.S., Myneni, S.C.B., Nilsson, A., Ogasawara, H., Ogletree, D.F., Pecher, K., Salmeron, M., Shuh, D.K., Tonner, B., Tyliszczak, T., Warwick, T., Yoon, T.H., 2006. Soft X-ray microscopy and spectroscopy at the molecular environmental science beamline at the Advanced Light Source. J. Electron. Spectrosc. Relat. Phenom. 150, 86104.

Bourbin, M., Gourier, D., Derenne, S., Binet, L., Le Du, Y., Westall, F., Kremer, B., Gautret, P., 2013. Dating carbonaceous matter in archean cherts by electron paramagnetic resonance. Astrobiology 13, 151-162.

Brasier, M.D., Green, O.R., Jephcoat, A.P., Kleppe, A.K., Van Kranendonk, M.J., Lindsay, J.F., Steele, A., Grassineau, N.V., 2002. Questioning the evidence for Earth's oldest fossils. Nature 416, 76-81.

Brasier, M.D., Wacey, D., 2012. Fossils and astrobiology: New protocols for cell evolution in deep time. Int. J. Astrobiol. 11, 217-228.

Chan, C.S., Fakra, S.C., Emerson, D., Fleming, E.J., Edwards, K.J., 2011. Lithotrophic iron-oxidizing bacteria produce organic stalks to control mineral growth: implications for biosignature formation. Isme Journal 5, 717-727. 
Cosmidis, J., Benzerara, K., Soft X-ray scanning transmission micro-spectroscopy, in: Gower, L., DiMasi, E., (Eds), Handbook of Biomineralization, Taylor and Francis, London, 2014.

Cosmidis, J., Benzerara, K., Gheerbrant, E., Estève, I., Bouya, B., Amaghzaz, M., 2013. Nanometer-scale characterization of exceptionally preserved bacterial fossils in Paleocene phosphorites from Ouled Abdoun (Morocco). Geobiology 11, 139-153.

Cuisinier, F., Bres, E.F., Hemmerle, J., Voegel, J.C., Frank, R.M., 1987. Transmission electron microscopy of lattice planes in human alveolar bone apatite crystals. Calcif. Tissue Int. 40, 332338.

Filip, Z., Herman, S., Demnerova, K., 2008. FT-IR Spectroscopic characteristics of differently cultivated Escherichia coli. Czech J. Food Sci. 26, 458-463.

Filip, Z., Herrmann, S., Kubat, J., 2004. FT-IR spectroscopic characteristics of differently cultivated Bacillus subtilis. Microbiol. Res. 159, 257-262.

García-Ruiz, J.M., Hyde, S.T., Carnerup, A.M., Christy, A.G., Van Kranendonk, M.J., Welham, N.J., 2003. Self-assembled silica-carbonate structures and detection of ancient microfossils. Science 302, 1194-1197.

Goulhen, F., Gloter, A., Guyot, F., Bruschi, M., 2006. Cr(VI) detoxification by Desulfovibrio vulgaris strain Hildenborough: Microbe-metal interactions studies. Appl. Microbiol. Biot. 71, 892-897.

Gourier, D., Binet, L., Scrzypczak, A., Derenne, S., Robert, F., 2004. Search for EPR markers of the history and origin of the insoluble organic matter in extraterrestrial and terrestrial rocks. Spectrochim Acta A Mol. Biomol. Spectrosc. 60, 1349-1357.

Gupta, N.S., Michels, R., Briggs, D.E.G., Evershed, R.P., Pancost, R.D., 2006. The organic preservation of fossil arthropods: An experimental study. Proc. R. Soc. B-Biol. Sci. 273, 2777-2783.

Hedges, J.I., Keil, R.G., 1995. Sedimentary organic matter preservation: an assessment and speculative synthesis. Mar. Chem. 49, 81-115.

Ingalls, A.E., Lee, C., Druffel, E.R.M., 2003a. Preservation of organic matter in mound-forming coral skeletons. Geochim. Cosmochim. Acta 67, 2827-2841.

Ingalls, A.E., Lee, C., Wakeham, S.G., Hedges, J.I., 2003b. The role of biominerals in the sinking flux and preservation of amino acids in the Southern Ocean along 170 degrees W. Deep-Sea Res. Pt Ii 50, 713-738.

Kaur, G., Mountain, B.W., Hopmans, E.C., Pancost, R.D., 2011. Preservation of microbial lipids in geothermal sinters. Astrobiology 11, 259-274.

Kaznatcheev, K.V., Karunakaran, C., Lanke, U.D., Urquhart, S.G., Obst, M., Hitchcock, A.P., 2007. Soft X-ray spectromicroscopy beamline at the CLS: Commissioning results. Nucl. Instrum. Meth. A 582, 96-99.

Kilcoyne, A.L.D., Tyliszczak, T., Steele, W.F., Fakra, S., Hitchcock, P., Franck, K., Anderson, E., Harteneck, B., Rightor, E.G., Mitchell, G.E., Hitchcock, A.P., Yang, L., Warwick, T., Ade, H., 2003. Interferometer-controlled scanning transmission X-ray microscopes at the Advanced Light Source. J. Synchrotron Radiat. 10, 125-136.

Konhauser, K., Riding, R., Bacterial Biomineralization, in: Knoll, H., Canfield, D.E., Konhauser, K.O., (Eds), Fundamentals of Geobiology, John Wiley \& Sons, Ltd, 2012, pp. 105-130, doi: 110.1002/9781118280874.ch9781118280878.

Lahfid, A., Beyssac, O., Deville, E., Negro, F., Chopin, C., Goffé, B., 2010. Evolution of the Raman spectrum of carbonaceous material in low-grade metasediments of the Glarus Alps (Switzerland). Terra Nova 22, 354-360.

Lalonde, S.V., Konhauser, K.O., Reysenbach, A.L., Ferris, F.G., 2005. The experimental silicification of Aquificales and their role in hot spring sinter formation. Geobiology 3, 41-52.

Lewan, M.D., Roy, S., 2011. Role of water in hydrocarbon generation from Type-I kerogen in Mahogany oil shale of the Green River Formation. Org. Geochem. 42, 31-41.

Li, J.H., Benzerara, K., Bernard, S., Beyssac, O., 2013a. The link between biomineralization and fossilization of bacteria: Insights from field and experimental studies. Chem. Geol. 359, 49-69. 
Li, J.H., Pan, Y.X., Liu, Q.S., Yu-Zhang, K., Menguy, N., Che, R.C., Qin, H.F., Lin, W., Wu, W.F., Petersen, N., Yang, X.A., 2010. Biomineralization, crystallography and magnetic properties of bullet-shaped magnetite magnetosomes in giant rod magnetotactic bacteria. Earth Planet. Sci. Lett. 293, 368-376.

Li, Y.L., Konhauser, K.O., Kappler, A., Hao, X.L., 2013b. Experimental low-grade alteration of biogenic magnetite indicates microbial involvement in generation of banded iron formations. Earth Planet Sc. Lett. 361, 229-237.

Lis, G.P., Mastalerz, M., Schimmelmann, A., Lewan, M.D., Stankiewicz, B.A., 2005. FTIR absorption indices for thermal maturity in comparison with vitrinite reflectance R0 in type-II kerogens from Devonian black shales. Org. Geochem. 36, 1533-1552.

Lowenstam, H.A., 1981. Minerals formed by organisms. Science 211, 1126-1131.

Miot, J., Benzerara, K., Kappler, A., 2014. Investigating microbe-mineral interactions: Recent advances in X-ray and electron microscopy and redox-sensitive methods. Annu. Rev. Earth Pl. Sc. 42, In press.

Miot, J., Benzerara, K., Morin, G., Kappler, A., Bernard, S., Obst, M., Ferard, C., Skouri-Panet, F., Guigner, J.M., Posth, N., Galvez, M., Brown, G.E., Guyot, F., 2009. Iron biomineralization by anaerobic neutrophilic iron-oxidizing bacteria. Geochim. Cosmochim. Acta 73, 696-711.

Miot, J., Maclellan, K., Benzerara, K., Boisset, N., 2011. Preservation of protein globules and peptidoglycan in the mineralized cell wall of nitrate-reducing, iron(II)-oxidizing bacteria: a cryoelectron microscopy study. Geobiology 9, 459-470.

Mrozowski, S., 1988. ESR Studies of carbonization and coalification processes Part II. Biological materials. Carbon 26, 531-541.

Oehler, J.H., Schopf, J.W., 1971. Artifical microfossils: Experimental studies of permineralization of blue-green alage in silica. Science 174, 1229-1231.

Orange, F., Westall, F., Disnar, J.R., Prieur, D., Bienvenu, N., Leromancer, M., Defarge, C., 2009. Experimental silicification of the extremophilic Archaea Pyrococcus abyssi and Methanocaldococcus jannaschii: Applications in the search for evidence of life in early Earth and extraterrestrial rocks. Geobiology 7, 403-418.

Paris, C., Lecomte, S., Coupry, C., 2005. ATR-FTIR spectroscopy as a way to identify natural proteinbased materials, tortoiseshell and horn, from their protein-based imitation, galalith. Spectrochim. Acta A: Mol. Biomol. Spectrosc. 62, 532-538.

Papineau, D., De Gregorio, B.T., Stroud, R.M., Steele, A., Pecoits, E., Konhauser, K., Wang, J.H., Fogel, M.L., 2010. Ancient graphite in the Eoarchean quartz-pyroxene rocks from Akilia in southern West Greenland II: Isotopic and chemical compositions and comparison with Paleoproterozoic banded iron formations. Geochim. Cosmochim. Acta 74, 5884-5905.

Pleshko, N., Boskey, A., Mendelsohn, R., 1991. Novel infrared spectroscopic method for the determination of crystallinity of hydroxyapatite minerals. Biophys. J. 60, 786-793.

Ransom, B., Kim, D., Kastner, M., Wainwright, S., 1998. Organic matter preservation on continental slopes: Importance of mineralogy and surface area. Geochim. Cosmochim. Acta 62, 1329-1345.

Ravel, B., Newville, M., 2005. ATHENA, ARTEMIS, HEPHAESTUS: data analysis for X-ray absorption spectroscopy using IFEFFIT. J. Synchrotron Radiat. 12, 537-541.

Sadezky, A., Muckenhuber, H., Grothe, H., Niessner, R., Pöschl, U., 2005. Raman microspectroscopy of soot and related carbonaceous materials: Spectral analysis and structural information. Carbon 43, $1731-1742$.

Seewald, J.S., 2001. Aqueous geochemistry of low molecular weight hydrocarbons at elevated temperatures and pressures: Constraints from mineral buffered laboratory experiments. Geochim. Cosmochim. Acta 65, 1641-1664.

Skrzypczak-Bonduelle, A., Binet, L., Delpoux, O., Vezin, H., Derenne, S., Robert, F., Gourier, D., 2008. EPR of radicals in primitive organic matter: A tool for the search of biosignatures of the most ancient traces of life. Appl. magn. Reson. 33, 371-397. 
Solomon, D., Lehmann, J., Kinyangi, J., Liang, B.Q., Heymann, K., Dathe, L., Hanley, K., Wirick, S., Jacobsen, C., 2009. Carbon (1s) NEXAFS spectroscopy of biogeochemically relevant reference organic compounds. Soil Sci. Soc. Am. J. 73, 1817-1830.

Stankiewicz, B.A., Briggs, D.E.G., Michels, R., Collinson, M.E., Flannery, M.B., Evershed, R.P., 2000. Alternative origin of aliphatic polymer in kerogen. Geology 28, 559-562.

Studier, F.W., Moffatt, B.A., 1986. Use of bacteriophage T7 RNA polymerase to direct selective highlevel expression of cloned genes. J. Mol. Biol. 189, 113-130.

Toporski, J.K.W., Steele, A., Westall, F., Thomas-Keprta, K.L., McKay, D.S., 2002. The simulated silicification of bacteria: New clues to the modes and timing of bacterial preservation and implications for the search for extraterrestrial microfossils. Astrobiology 2, 1-26.

Trchová, M., Stejskal, J., 2011. Polyaniline: The infrared spectroscopy of conducting polymer nanotubes (IUPAC Technical Report). Pure Appl. Chem. 83, 1803-1817.

Van Zuilen, M.A., Chaussidon, M., Rollion-Bard, C., Marty, B., 2007. Carbonaceous cherts of the Barberton Greenstone Belt, South Africa: Isotopic, chemical and structural characteristics of individual microstructures. Geochim. Cosmochim. Acta 71, 655-669.

Vandenbroucke, M., Largeau, C., 2007. Kerogen origin, evolution and structure. Org. Geochem. 38, 719833.

Watson, J.S., Fraser, W.T., Sephton, M.A., 2012. Formation of a polyalkyl macromolecule from the hydrolysable component within sporopollenin during heating/pyrolysis experiments with Lycopodium spores. J. Anal. Appl. Pyrolysis 95, 138-144.

Weiner, S., Dove, P.M., 2003. An overview of biomineralization processes and the problem of the vital effect. Biomineralization 54, 1-29.

Westall, F., Boni, L., Guerzoni, E., 1995. The experimental silicification of microorganisms. Palaeontology 38, 495-528.

Yule, B.L., Roberts, S., Marshall, J.E.A., 2000. The thermal evolution of sporopollenin. Org. Geochem. $31,859-870$. 


\section{Figure captions}

554 Figure 1. Morphological alteration of non-calcified E. coli cells (a and b) and calcified E. coli cells (c and 555 d) after heating treatments. (a) TEM image of E. coli cells dehydrated at room-temperature for two weeks.

556 (b) TEM image of E. coli cells heated at $300^{\circ} \mathrm{C}$ for $2 \mathrm{~h}$. The morphological structure of E. coli cells was 557 completely lost after heating at 300 or $600^{\circ} \mathrm{C}$, even in the 2-h long experiments. (c) SEM and TEM (inset) 558 image of calcified E. coli cells dehydrated at room-temperature. (d) SEM and TEM (inset) image of 559 calcified $E$. coli heated at $600^{\circ} \mathrm{C}$ for $20 \mathrm{~h}$. SEM and TEM analyses show that the $E$. coli cells were heavily 560 aggregated and encrusted by whisker-shaped minerals, and that the morphological structures including 561 encrusted cells (indicated by single-ended arrow with a solid line) and cell aggregates were well 562 preserved after all heating experiments.

564 Figure 2. (a) Raman spectrum of non-calcified E. coli cells heat at $600^{\circ} \mathrm{C}$ for $20 \mathrm{~h}$. The spectrum was 565 deconvoluted with a four-band fitting $(G, D 1, D 2$ and $D 3)$ using a Voigt profile, as described in Beyssac et al. (2002). (b) EPR spectra of non-calcified and calcified E. coli cells heat-treated at $600^{\circ} \mathrm{C}$ for 20 h. (c) Description of the EPR line shape of the two samples. $\Delta B_{\mathrm{pp}}$ and $A_{\mathrm{pp}}$ indicate the peak-to-peak line width and amplitude, respectively, $\Delta B$ is the magnetic field offset from the line center, and $A$ is EPR amplitude values at each point of the EPR line. The line shape parameter $R_{10}$, which was calculated following Skrzypczak-Bonduelle et al. (2008), is used to quantify the deviations of the experimental points from the Lorentzian shape in this plot.

Figure 3. C K-edge XANES spectra of heat-treated E. coli cells. The peaks at $285.2 \mathrm{eV}, 287.3 \mathrm{eV}, 287.8$ $\mathrm{eV}, 288.2 \mathrm{eV}, 288.5 \mathrm{eV}$, and $289.4 \mathrm{eV}$ correspond to electronic transitions in aromatic $(\mathrm{C}=\mathrm{C})$, alcohol (C$\mathrm{O})$, aliphatics $(\mathrm{C}-\mathrm{C})$, amide $\left(\mathrm{O}=\mathrm{C}-\mathrm{NH}_{\mathrm{x}}\right)$, carboxyl $(\mathrm{O}=\mathrm{C}-\mathrm{O})$, and alcohol $(\mathrm{C}-\mathrm{O})$ functional groups, respectively. The peaks at $297.3 \mathrm{eV}$ and $300 \mathrm{eV}$ correspond to the potassium $L_{2,3}$-edges indicating the presence of $\mathrm{K}$ most likely precipitated from the culture medium.

Figure 4. Infrared spectra of non-heated and thermally treated samples of non-calcified (a) and calcified (b) E. coli cells. The bands at 2958-2854 $\mathrm{cm}^{-1}$ correspond to C-H stretching in aliphatics. The peak 1702 $581 \mathrm{~cm}^{-1}$ corresponds to $\mathrm{C}-\mathrm{O}$ stretch of $\mathrm{CO}_{2} \mathrm{H}, 1655 / 1652 \mathrm{~cm}^{-1}$ to amide I, $1628 \mathrm{~cm}^{-1}$ to aromatic band $\mathrm{C}=\mathrm{C}$, $5821540 \mathrm{~cm}^{-1}$ to amide II, $1455 \mathrm{~cm}^{-1}$ to $\mathrm{C}-\mathrm{H}$ deformations of $\mathrm{CH}_{2}$ or $\mathrm{CH}_{3}$ groups in aliphatics, $1393 \mathrm{~cm}^{-1}$ to $583 \mathrm{C}-\mathrm{H}$ bending, $1265 \mathrm{~cm}^{-1}$ to $\mathrm{C}=\mathrm{O}$ stretch of $-\mathrm{COOH}, 1237 \mathrm{~cm}^{-1}$ to amide III, $1082 \mathrm{~cm}^{-1}$ to $\mathrm{C}=\mathrm{O}$ stretching. 584 The peaks at $565 \mathrm{~cm}^{-1}$ and $603 \mathrm{~cm}^{-1}$ correspond to P-O-P bending, and $1035 \mathrm{~cm}^{-1}$ to P-O stretching of $\mathrm{PO}_{4}$ 
585 groups, or to the vibrational modes of $\mathrm{OH}^{-}$groups. The small peaks at $1093 \mathrm{~cm}^{-1}$ and $962 \mathrm{~cm}^{-1}$ correspond 586 to P-O-P bending. 


\section{Supplementary Figure Captions}

590 Figure S1. Morphological and chemical characterization of non-heated calcified E. coli cells. (a) SEM 591 image of heavily encrusted and aggregated calcified E. coli cells. (b) STEM image showing minerals 592 located within the cells, within the cell walls and at the cell surfaces. (c) TEM image showing the high 593 amount of minerals at the cell surface. (d)-(i) STEM-XEDS maps showing the spatial distribution of C, O, $594 \mathrm{P}$ and Ca. (j) SAED pattern of the Ca-phosphate minerals. The d-spacing values calculated from two 595 major electron diffraction rings are 3.44 and $2.75 \AA$, which can be indexed as the (002) and (121) lattice 596 planes of hydroxyapatite, respectively . (k) HRTEM image of hydroxyapatite crystals.

597

598 Figure S2 Morphological and chemical characterization of calcified E. coli cells after heated at $600^{\circ} \mathrm{C}$ for 59920 h. (a) SEM image. (b) STEM image. (c) TEM image. (d)-(i) STEM-XEDS maps of C, O, P and Ca. (i) 600 SAED pattern showing the Ca-phosphate minerals are still hydroxyapatite. (k) HRTEM image of the 601 hydroxyapatite minerals. SEM and TEM analyses altogether reveal a good morphological preservation of 602 calcified E. coli cells after heating treatments. SAED and HRTEM lattice imaging also show an increase 603 of crystallinity of hydroxyapatite crystals after heating treatments, e.g., sharper and narrower electron 604 diffraction rings recorded from the $600^{\circ} \mathrm{C}-20 \mathrm{~h}$-heated sample compared to the unheated one. 
(1) The biogenicity of microfossils is often debated because of morphological and chemical alteration during geological history.

(2) We experimentally studied the effect of bacterial biomineralization on fossilization during thermal treatments.

(3) Calcified E. coli were better preserved morphologically and chemically during heating up to $600^{\circ} \mathrm{C}$ and $100 \mathrm{~h}$.

(4) These evidence the influence of bio-encrustation on bacteria preservation potential during fossilization processes.

(5) Self-encrusting microorganisms should be considered as pertinent targets for the search for ancient life in fossil record. 
Click here to download high resolution image

Non-heated

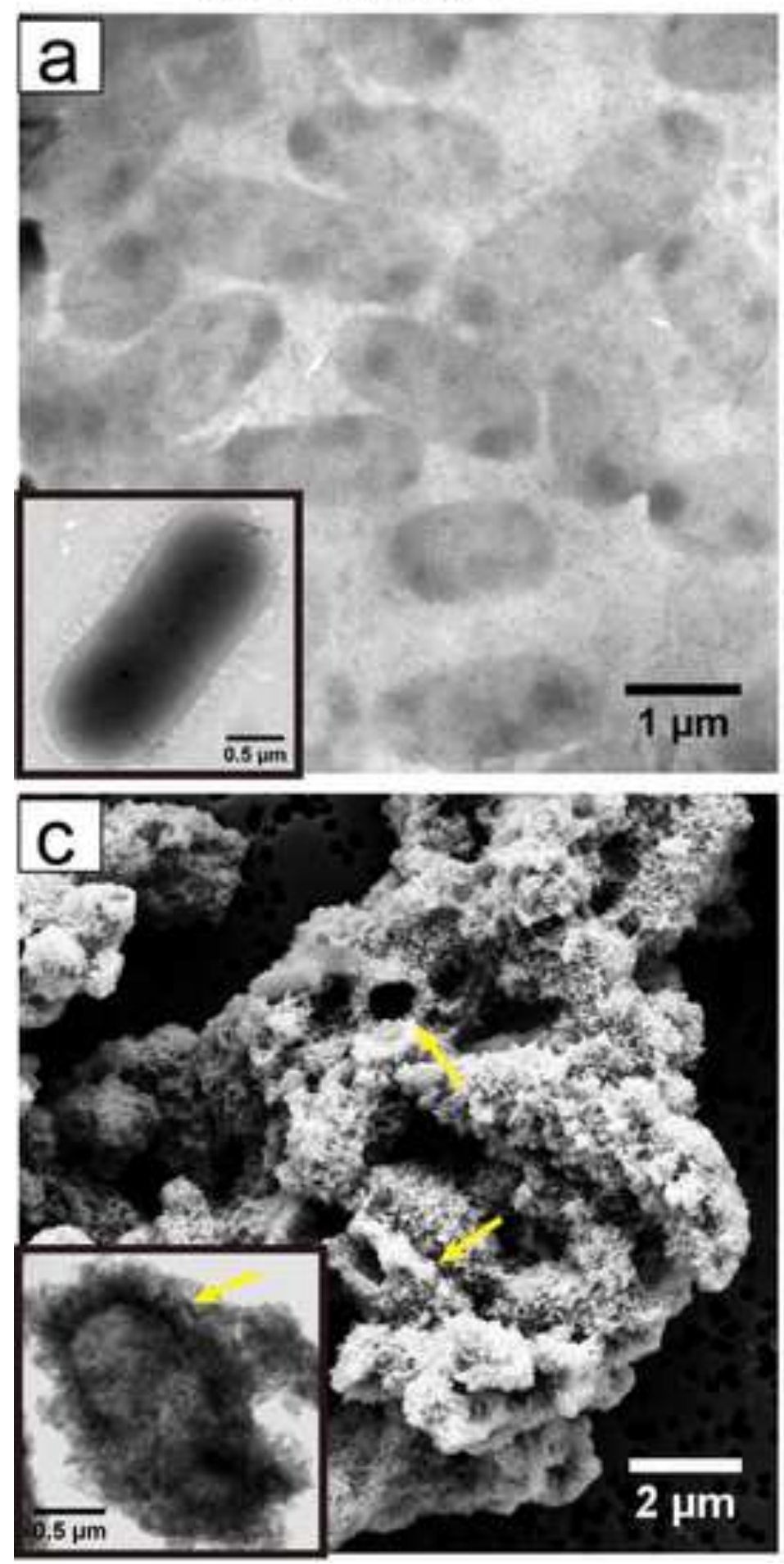

Heated
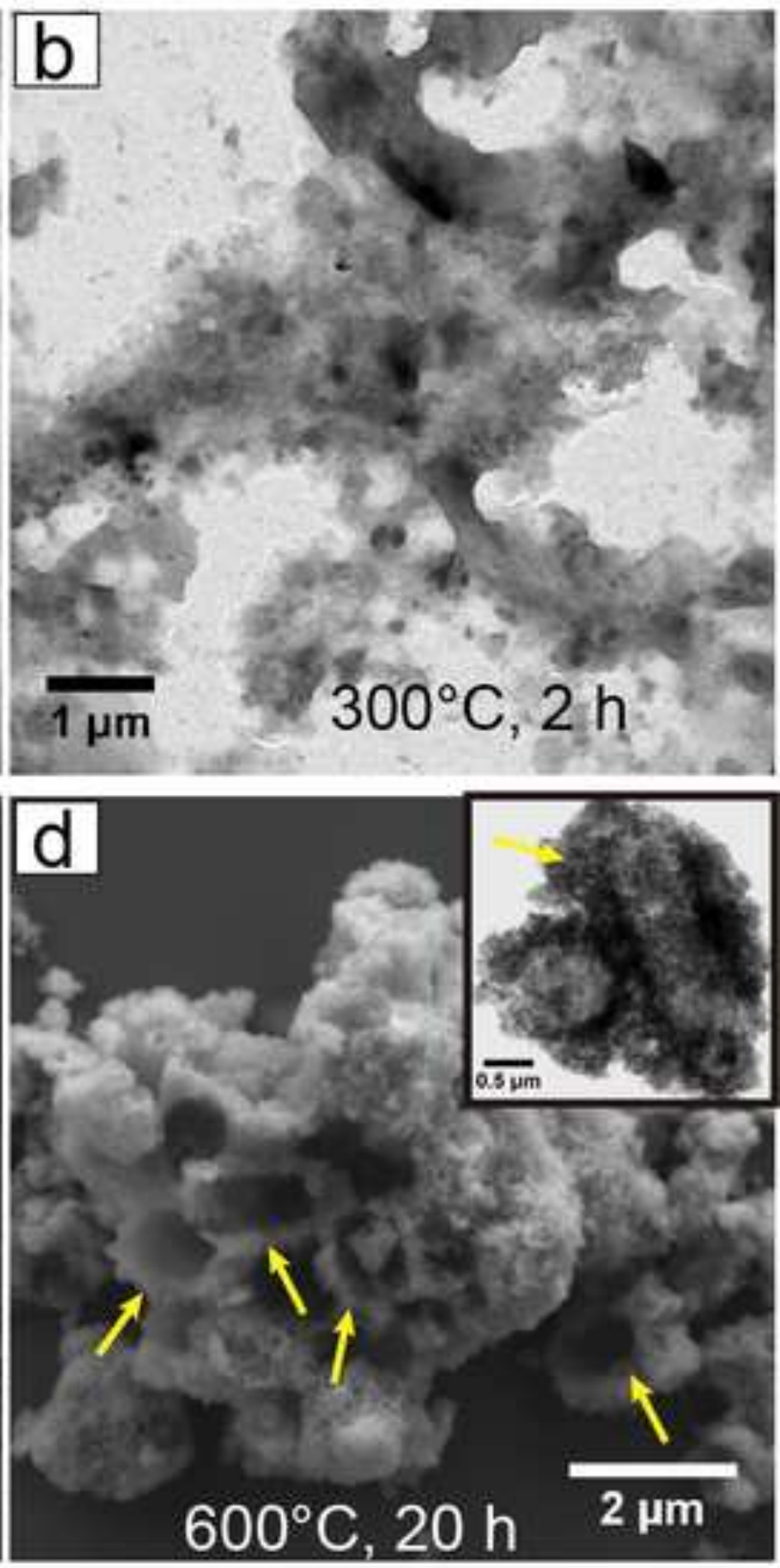

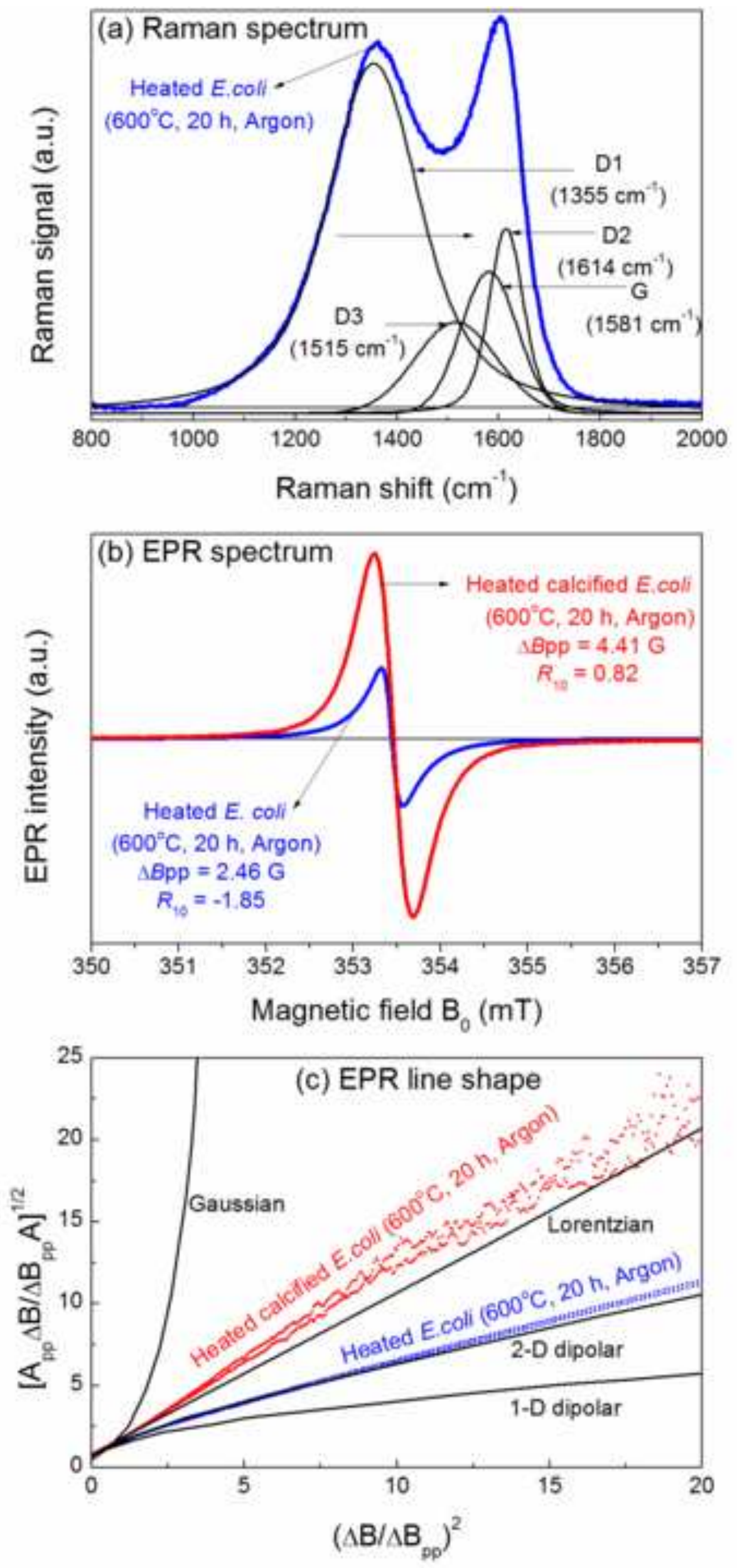


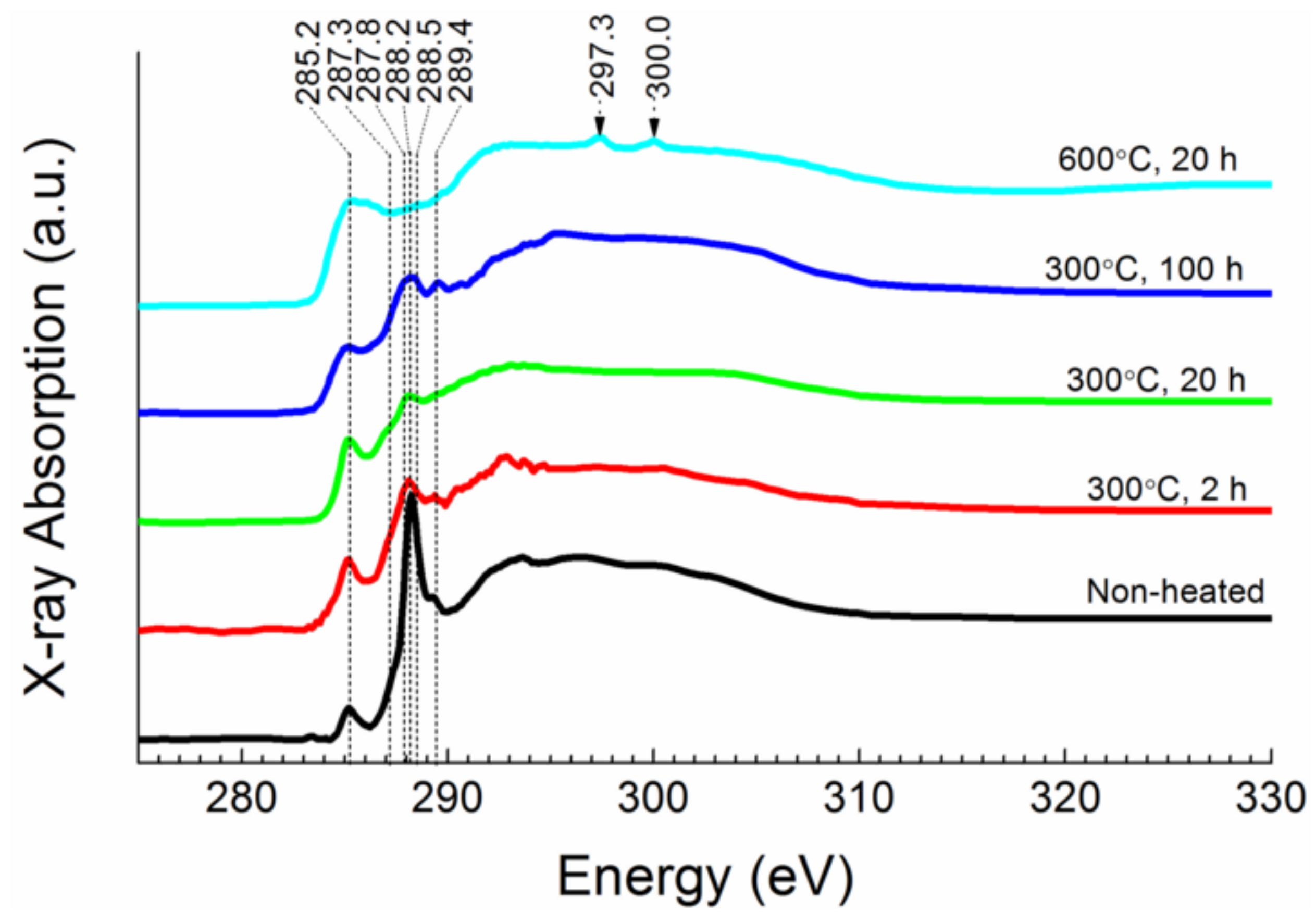



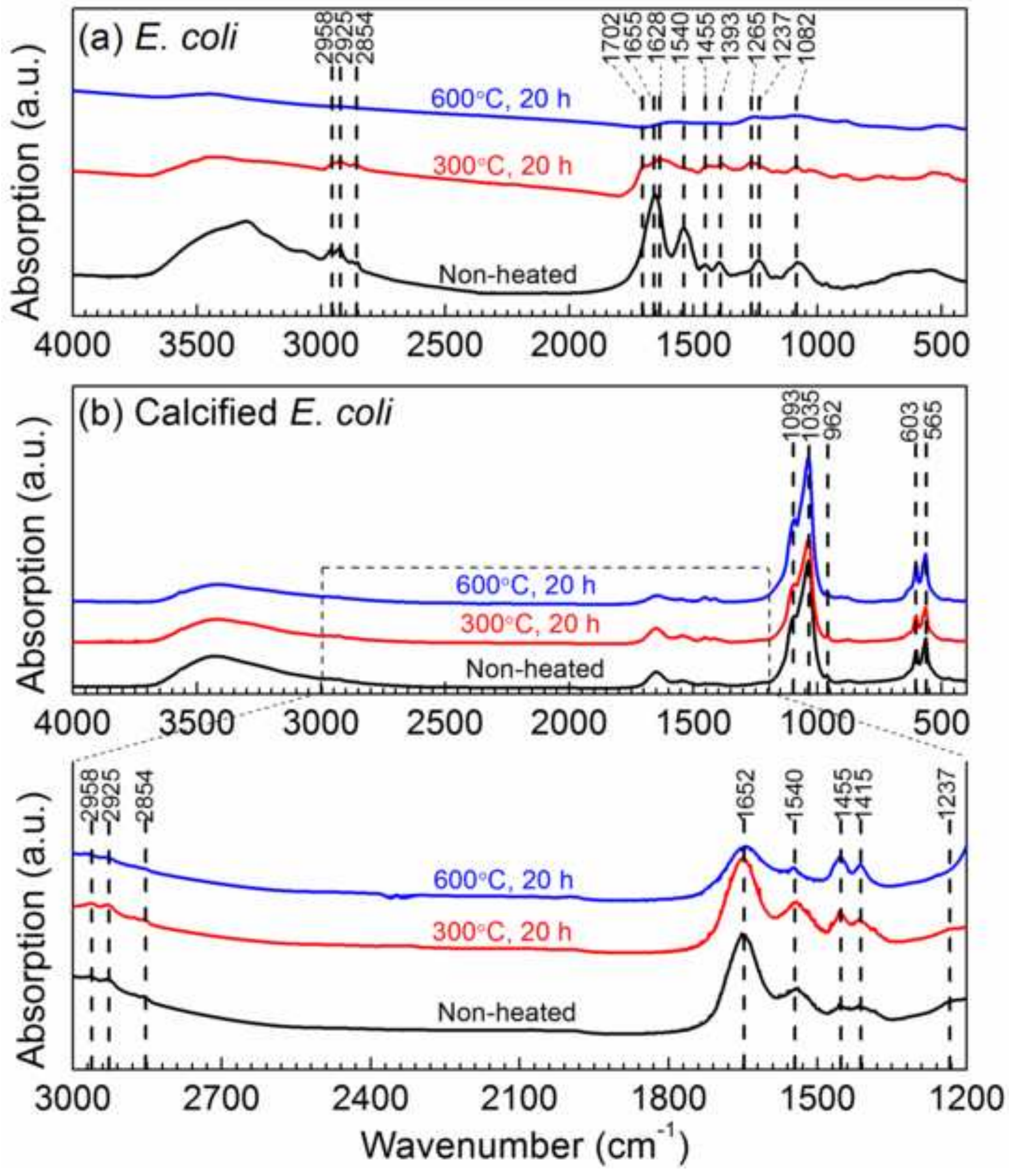